\section{CHEMISTRY IN THE SERVICE OF MAN*}

\author{
By DR. E. F. ARMSTRONG, F.R.S.
}

$\mathrm{C}$ HEMISTRY is the science which has discovered how things are composed, what properties they have and how they will react. Chemistry not only tells all about natural substances but also enables us to make new products rivalling the natural products in utility. Some of these safeguard health, others provide clothing, propel motor-cars, do a thousand other things and promise much more in future.

The manufacture by chemical synthesis of thousands of tons of substances of use to man depends on the availability of large quantities of suitable raw materials. The chemist wishing to make carbon compounds, which are without exception made up of longer or shorter chains of carbon atoms joined one to the other, seeks to start as early in the series as possible, generally from substances containing only two carbon atoms represented thus - C - C - in his graphic formulæ.

To found a large-scale industry which is to handle many tens of thousands of tons, the raw material must be available in plenty and at world prices. It must bear no tax at this stage, a point largely overlooked by our politicians, or any other avoidable burden; in short, the price must be as low here in Britain as it is anywhere else in the world if the home industry is to be competitive.

The problem in making the large molecules or polymers composed of repeating units, which constitute many of the plastic materials, is to induce a large number of relatively small molecules to join together by chemical means. It would be a difficult and costly operation if we had to build the large molecule step by step ; fortunately there is a triggerlike action between two carbon units at a high temperature, so that the energy set loose when they combine brings about a chain reaction in which perhaps a thousand units join together. The chemist has learned how to control the growth of the molecule so that the most suitable molecule-length may be obtained to suit the particular purpose for which the polymer is to be used.

The search for raw materials thus becomes one for two-carbon compounds; there are several alternative sources of these which it is proposed to examine here primarily in relation to their availability in Britain and the British Empire.

(1) Acetylene made by the action of water on calcium carbide, which in its turn is made from lime and coke by processes which need very large quantities of electric power : this power must necessarily be low-priced. In general such power, either in quantity or price, is not available in Britain, and it is not considered that any of the carbide production will be available for chemical synthesis.

(2) Two-carbon compounds made from alcohol by simple large-scale processes. Industrial alcohol is made by fermentation of carbohydrate materials, in particular from molasses which is imported in tank steamers just as is crude oil. It is recovered from the spent mash by distillation: other commercia] products of the operation are carbon dioxide used to make 'dry ice' for refrigeration, and yeast. The formation of fermentable carbohydrates by plants is

* Extracts from the inaugural address to the Royal Society of Arts, delivered on November 1 . largely a function of the amount of sunlight-tropical countries have a great advantage over Britain in this respect. Our home cereals, required to feed man and beast, are too valuable to turn into alcohol except that limited quantity which is so profitably sold as potable spirits. The West Indian and other colonies need an outlet for their surplus carbohydrate material, and it is probable that industries can be developed there on the largest scale to produce material which can be easily transported to Britain for fermentation to alcohol.

(3) Two-carbon compounds made by the cracking of petroleum products. This industry is a modern adjunct to the refining industry which makes petrol, lubricating oils and burning oils.

(4) Two-carbon compounds made by catalytic synthesis from water gas and hydrogen. As water gas is made from coke, this is a simple form of oil from coal.

The oil-refining industry is only to a very minor extent established in Great Britain, since the discovery of a small native source of petroleum is a recent one. An increasing number of people consider its absence to be a very serious handicap, both because the country is deprived of these cracking products as the basis of the new chemical industry and because also the lack of this industry will mean the loss of incentive to our young men to become chemical engineers, of which more anon. The economic future of the synthetic, often called the Fischer Tropsch, process is still uncertain. It has been largely developed in Germany for military considerations.

Apparently if Britain is to develop these new synthetic chemical industries, the raw materials will be alcohol and/or cracking products. Both are being used to-day in America and there is the keenest competition between them, for example, as to which is the best raw material for the manufacture of synthetic rubber. Reports seem to indicate that the alcohol process is coming out well, which is of good augury for Great Britain where, as my analysis shows, it may be the most readily obtained raw material.

There is a great future for agriculture to supply raw materials, especially for chemical industry, sometimes called chemurgical materials. The sun and the rain and the soil enable man by the sweat of his brow to produce foodstuffs for man and beast. It is a wasteful process; too much depends on a variable market with manipulated prices, and much that is grown is left to decompose into simple products which return to the soil and the air. With cheap transport available and good organization, it should be possible to transform far more of what is grown into alcohol or protein and to lessen the waste. If this can be realized, great new employing industries can be set up in Britain and every yard of ground will be turned to account.

Lord Bledisloe has quoted with approval a statement "this nonsense world has too much chemistry, forgetting the living earth". Perhaps he is right in relation to farming, but reference is here made to the use of farm products as raw materials. In fact, there is need for more chemistry to help use the products of the farm, and we cannot do better than quote Mr. G. A. Sloan, president of the Nutrition Foundation :

"We think of cattle, corn, peanuts and soya beans primarily as food. In the future we will think of them also as sources of penicillin, synthetic fibres, hormones, vitamins, plastics and a host of new products which 
will increase the return to the farmers who raise them."

Some say we have not room to grow carbohydrates for alcohol in Britain, since we have only $1 \frac{1}{4}$ acres per head of population. At least, we can avoid much waste, and there is the whole of the British Empire.

War experience has already taught that there is an economic use for all we grow when scarcity makes us take heed of our resources. Chickens, pigs, animal meat are not economic; milk production is ! It is claimed, though not yet proved, that the yield of protein per acre in the form of yeast made from molasses calculated on the area of land required for the production of the molasses is several times greater than that of protein grown as soya beans, which have a high content of protein. It is also higher per acre than that obtained by feeding fodder crops to animals. In other words, 100 acres of sugar beet turned into molasses, turned into yeast would give more protein than 100 acres of grazing land turned into beef. These are the kind of sums which we may have to work out in the future.

The chemist has done much for food and will do increasingly more. There is an entirely proper prejudice in favour of fresh untreated foods; but we must, at least, know and understand everything about each one of them, and where the chemist can aid to make them safer to eat, more available, and guide their choice, his help should not be refused.

I wish here to direct attention to another phase of the food question, namely, that concerning proteins. Each protein is made up of a number of molecules of amino-acids, of which there are twenty different kinds. The protein molecules are very large, containing a thousand and more amino-acid molecules; they differ in the percentages of the various aminoacids present and may lack some of them altogether or contain the smallest quantities only. The individual amino-acids are joined end to end in a chain, the exact pattern of which has not yet been established for any protein; it is known to be constant for each particular protein.

The body breaks down the proteins, it eats into the individual amino-acids and uses these again to make its own protein: hence the importance of the individual amino-acids. Man and animals need most of them. Probably meat protein is so important a food because it contains those very amino-acids which we use to make muscle tissue. Nutrition experts are quite clear that a mixed diet is the best as a source of protein.

The scarcity, at least in war, and the cost of proteins make their economic production a matter of extreme importance. One main source is meat from animals, which convert vegetable protein in herbage into beef and mutton and pork; the process is a slow one. Another source is the pulses, seeds of high protein content which can be improved by selection and cultivation. Another source is fish.

The widespread cultivation of the soya bean is a notable example of progress in protein production. Unfortunately, this vegetable protein only ranks as second-class. Considerable interest, therefore, is attached to the production of protein in the form of yeast, which can be multiplied very rapidly in the course of a few hours. Whereas animals make their protein from the small amounts of organic vegetable protein in the very large quantities of herbage which they consume, the yeast cell is able to make its protein from ammonium salts, which are inorganic and manufactured from the nitrogen in the air. The technical question becomes whether yeast can be made in large quantity from carbohydrate material and inorganic nitrogen (ammonia) at a competitive price with meat. Inorganic nitrogen, a product of high-pressure technique, is to-day very cheap and available in unlimited quantity.

It is worth while giving some data about yeast production. They are based on U.S. experience. Baker's yeast is the chief yeast product; it is made to-day from carefully cultured strains having standardized activity in causing bread dough to rise in an appropriate number of minutes. Some 100,000 tons will be made in 1944. The vitamin content is not high, but it is possible to enhance it by changing the nutrient. Brewers' yeast is essentially a byproduct of the fermentation of beer, and is not a raw material for another industry - more than 12,000 tons are available as a slurry, of which about one-third is recovered as cattle food and about one-tenth used as food or sold in the pharmacy. The vitamin content is some three times as great as that of bakers' yeast. The acceptance of brewers' yeast as food has led to the production in America of this type, grown especially for the yeast, that is, without hops, so that the product need not be debittered. The dried yeast has a high content of the vitamin $\mathrm{B}$ complex and retails for some $3 s$. a pound, a price which is reasonable on the basis of its protein content, which is about 46 per cent. A little calculation shows that yeast protein costs about $6 s$. $6 d$. per pound retail, whereas beef, with 19 per cent protein, selling at $2 s$. a pound, involves a protein cost of $11 s$. a pound. These figures are but an indication, but they are very sug. gestive of what can be done in the way of making protein quickly. Beef protein takes a year or more to make, yeast protein is a matter of twenty-four hours; beef certainly needs a larger acreage.

A specially suitable race of the yeast (Torula utilis) for the purpose has been recently developed in London, and factories are understood to be under construction to make it in Jamaica and Mauritius, where its first use will be for the under-nourished children in those Colonies. In the tropics, protein scarcity is often severe, but waste carbohydrates are plentiful. Certain races of yeast multiply so rapidly that the alcoholic fermentation is practically negligible. The yield of dried yeast in practice is 60 per cent of the fermentable sugar. It has been estimated in Germany that the waste sulphite liquors of the paper mills could make 100,000 tons of dry yeast a year, equivalent to 50,000 tons of protein. A development which is not very remote is the making of fermentable carbohydrates from wood. By what is known as the Scholler process, wood in presence of dilute sulphuric acid at a pressure of 4 atmospheres, the temperature being taken up to $190^{\circ} \mathrm{C}$., is converted into easily fermentable glucose.

Largely within one generation, Britain and the United States have passed from a stage in which most of our food supply went directly from the farm to the consumer, to the present development in which the food industry processes and distributes a large and growing part of the total food supply. This could not have happened had it not been possible for the industry to do the job more efficiently, to provide better foods for the public at low cost. At first the development appeared to be on wrong lines from the point of view of optimum health, but the timely discovery of the importance of vitamins and the way to preserve and, indeed, obtain them has 
altered this and made industry distribution of food of real benefit to mankind.

I would say a word about chemistry as a career. The nation needs many thousands of chemists, and the profession will attract an increasing number of young men. But the need is for enthusiasts with a real call to study and discover and make the furtherance of chemistry their life-work; those who think only that chemistry will give them an easy livelihood should be discouraged from entering the profession.

There will be countless opportunities in industry; in research and teaching, as well as in the professional branches of chemistry-the wise man will try to get experience in several of these before he settles down to his preference. While the material reward is important, and chemists, like others, must be properly paid, it is not-everything, and many must be left free to pursue science for its own sake.

There is a tendency to place the utilitarian aspect of science too high, to associate universities, teachers and research with industrial development. This may have grave dangers if pursued too far; the universities must be left unfettered to pursue pure science, and endowed so as to make this possible. Their main function must remain to advance science for its own sake and they must avoid becoming tied to the wheel of commerce. "The wind of genius bloweth where it listeth."

In advocating the much more general teaching of science and scientific method throughout the schools, it is the scientific habit of thought that it is desired to cultivate, not mere scientific knowledge. The socalled practical man affects to despise theory, but he usually has a fairly intimate knowledge of his materials, gained by long experience, while if he is really practical, his methods are not far different from those of science. Where a knowledge of scientific method can help is in enabling new experiments to be devised which have a fair chance of success, or at least of teaching something. I have seen to my sorrow during this War far too many costly experiments made, the result of which a scientific man with knowledge could have easily predicted and which, therefore, were a waste of time and money.

The engineer, who is largely ruled by tradition, has intimate knowledge of the metals, but is being faced with the most varied requirements by industry for special plant to work at high temperatures and pressures, and to contain substances with corrosive and other unpleasant properties. To meet these difficulties a new class of engineer has arisen, the so-called chemical engineer, who supplements a sound general knowledge of engineering by a specialized knowledge of applied chemistry. There are degree courses at certain British universities for the training of such men. Actually, the country needs a great many more of them, perhaps several thousands, and the facilities for training them must be immediately increased.

I like to think of chemists as voyagers to a New World on uncharted seas of discovery, possessed of an Elizabethan quality as merchant adventurers. The Elizabethan age was one which had a soaring confidence; statesmen were not afraid to be something else as well-Bacon was alike man of science and philosopher. Science, industry, commerce, require art and skill to guide them; they need vitality for creative effort. It is our task to help to find them. It is not enough to search for true knowledge, for it is in the use of that knowledge we shall build our future.
The influence of war in accelerating scientific progress is often made the subject of comment. The reason for the greatly accelerated tempo is not far to seek-the needs are urgent, money is of no object, large-scale experiments are made possible, ample man-power is available. To Napoleon is credited the introduction of sugar beet in France to substitute for the West Indian sugar denied him by the blockade of the English Fleet; he also began the research which led to the preservation of foods by canning. This War has taken food preservation a stage further and developed the dehydration processing of food and much beside in the food industry: transport difficulties brought about by the submarine have forced these developments and produced a revolution, internal and external, in methods of transporting and preserving foodstuffs. Margarine was introduced during the 1870 War, but its development lagged until the War of 1914-18, and has been completed during this War, so as to put it on parity with butter. Perhaps the chief effect will be the great simplification of the problem of distributing food on a worldwide scale. Places and countries which are far distant, hard to reach and unhealthy, can now have normal healthy food supplies assured. Given also the advantages of refrigeration and air-conditioning, with power produced by the petrol engine, pioneering will lose half its terrors, while airports will become oases in the most savage lands.

Perhaps the person who is really encouraged by war is the technologist; hence the rather crude saying that science is useless until the technologist comes along and does something with the findings. Britain has made more than its quota contribution to discovery in pure research; it has largely left it to other nations to turn these discoveries to practical ends, and it is very slow to adopt them even when they are proved and of economic value.

It is comforting to read that even in the United States, where the speed of technical development is a cause for envy here, 'neophobia' exists, a term which means 'fear of the new' and that it may take ten or twenty years for a new product to become commercially successful. A wise friend of mine, H. A. Hopf, writes me that "every sensible person whose ideas are in advance of his times must have patience and persistence and a sense of humor".

It is claimed, and with a large degree of truth, that science, meaning the knowledge we have to-day in its various branches, has put those things which the individual wants, namely, food, work, security and freedom, within reach of all. The methods and ideas of science must become the dominant forms of thought and action in the future, but we must watch that talk is not substituted for action. Very few of those who offer Utopia to the public suggest that hard work will also be necessary and, indeed, must come first, if Utopia is to be earned. Forgotten is what Gilbert Cannan once expressed in "Pigs and Peacocks"- "laziness is the source of the whole trouble, letting the language, the traditions, the morals, the justice and the liberty of the race slip away"'; there will be many who think this is just what is happening to-day.

It is widely advocated that the man of science and the engineer must exhibit depth and breadth of learning, and in particular see that the gifts of science are not wrongly used. The intention is good, but no man can control what others do with his inventions or their development. In fact, the developments during war, into which no question of econ- 
omics is allowed to enter, are enormously greater and faster than they would have been during peace, and when peace comes mankind is assured of amazing benefits through them.

There is a hypothesis widely held by modern leaders of thought that the evolution of society, moving at an ever faster pace under the impetus given it by modern science, has up to now outstripped the eapacity of human beings to adapt themselves. It is asked in the words of Herbert Read, "Is there a pattern or is it chaos; is it empty turmoil or is it progress?" That the world needs skill and vision to rebuild none will gainsay. Can we not say we are men of science and we believe we have the skill ; we are artists and we believe we have the vision ? Herein lies the future of this Royal Society of Arts. Shall we not repeat those Biblical words: "Be ye doers of the word and not hearers only, deceiving your own selves".

Perhaps then we may say with Shelley :

"The world's great age begins anew The golden years return".

or with Carlyle: "Blessed is the man who has found his work-let him ask no further blessedness".

\section{THE BIOLOGY WAR COMMITTEE}

$T$ HE Biology War Committee was formed more than two years ago with the object of establishing a clearing-house through which ideas or knowledge relating to war-time biological problems could be exchanged between biologists and the Government. In order to ensure the closest liaison and co-operation, the Committee was linked to a special Joint Committee of the Department of Scientific and Industrial Research, the Medical Research Council, and the Agricultural Research Council. Moreover, it was agreed that while the Biology War Committee should cover the main fields of biology, medicine should be excluded and that representation should be weighted in favour of those fields which were not highly specialized and in which workers were not already elosely linked with the three Government research councils.

In the exploratory period following on its initiation, the Committee was concerned in organizing and also establishing contacts with both Government Departments and biologists. Attention was also given to discovering the types of biological problems most likely to arise under conditions of war.

During the last two years memoranda and reports on a variety of problems have been prepared, some at the request of the Joint Government Committee and many on the Committee's own initiative. In addition, many other suggestions, inquiries and problems have been considered. The Committee is not, however, in the position to make public any summary of its activities to date since, on the grounds of the national interest, the Joint Government Committee considers that references to specific problems would be inadvisable. The Biology War Committee can, therefore, only state that the range of problems touched on or investigated is remarkably wide. In several instances the solution has required collaboration not only between biologists of varied interests but also with other scientific workers. In fact the complexity of some biological problems, where only one link in the chain of causation may be concerned with living organisms, has obscured to non-biologists the realization that some war-time problems are in part biological. Again, lack of detailed knowledge has caused some confusion in assessing biological problems-for example, the tendency to group into broad categories and therefore a failure to distinguish between allied noxious and innocuous species.

When the original Committee, set up jointly by the Association of Applied Biologists, the British Ecological Society and the Society for Experimental Biology discussed the formation of the Biological War Committee with the Joint Government Committee, it was felt that the future Committee's usefulness would be enhanced if the composition was based solely on representation by subjects. The experience gained over the last two years has fully confirmed this view. At the same time, the Biology War Committee has been considering how best to ensure flexibility under the ehanging conditions of the War, and the need for maintaining close contact with biological societies.

With these ends in view, the Committee has been reviewing both its organization and its constitution. It has been decided that, as hitherto, much of the work can best be carried out by a small executive committee working in conjunction with sub-committees set up to deal with specific problems and with powers to co-opt members outside the Committee.

It has also been agreed that the membership of the full Committee should be reviewed annually and that before the final list of proposed members is settled, the list for the ensuing year should first be circulated to biological societies asking for their comments and suggestions as to the representation of subjects. In addition, it has also been resolved that two members of the executive committee, which includes the officers, should retire annually, and that only one member should be eligible for re-election. For the offices of chairman and vice-chairman, it has been decided that the tenure should not exceed one year, but that the secretary and treasurer should serve for three consecutive years.

After consultation with biological societies, the composition of the Biology War Committee for the ensuing twelve months is as follows: A. L. Bacharach; F. C. Bawden, Rothamsted Experimental Station, Harpenden; G. E. Blackman (secretary), Department of Botany, Imperial College of Science and Technology, London, S.W.7; Prof. P. A. Buxton*, Department of Medical Entomology, London School of Hygiene and Tropical Medioine; Prof. H. G. Champion (vice-chairman), Imperial Forestry Institute, Oxford; Prof. A. C. Chibnall, Department of Biochemistry, Cambridge ; C. Elton, Bureau of Animal Population, Oxford; Prof. H. Munro Fox, Department of Zoology, Bedford College, London; Dr. W. P. K. Findlay, Forest Products Research Laboratory, Princes Risborough; Dr. H. Godwin*, Botany School, Cambridge; Dr. J. Hammond (treasurer), Animal Nutrition Research Institute, Cambridge; Prof. A. C. Hardy, Department of Natural History, Aberdeen; Dr. H. Martin*, Long Ashton Research Station, Bristol; Dr. K. Mather, John Innes Horticultural Institution, Merton, London; Dr. A. T. R. Mattick, National Institute for Research in Dairying, Shinfield, Nr. Reading; Prof. J. W. Munro, Department of Zoology and Applied Entomology, Imperial College of Science and Technology, S.W.7; Dr. J. Needham, Department of Biochemistry, Cambridge ; Dr. F. C. Pantin* (chairman), Department of Zoology, Cambridge ; Dr.

* Members of the Executive Committec. 